\title{
Cinco POEMAS DE PERROS MUY AZULES*
}

\section{Claudia Hernández de Valle Arizpe}

\section{I. (DE "SOLO")}

Ayer recorrí Tebas.

Al final de una larga pared había una pileta.

Aguardé mi turno.

Me unté el agua en la frente.

Me incliné con devoción.

Después, ya lejos de todos, caminé entre las ruinas.

Alguien del lugar me ofreció pan.

Me senté en una piedra a comerlo despacio entre luces y sombras que se agitaban con el paso de un rebaño.

En un lugar más frío me interceptó una muchacha que vendía joyas y telas.

La dejé atrás con un gesto.

Despedía un calor de vela.

Supe que había estado en Tebas; la griega, porque mi boca habló en el sueño.

*Perros muy azules fue editado por el Ministerio de Cultura de la República Dominicana en marzo de 2010. Obtuvo el Premio Iberoamericano de Poesía "Jaime Sabines" para Obra Publicada, 2010, y será editado en México en 2011. 


\section{II. (DE "SOLO")}

Lo mejor del río fue la libélula.

Su vibración sobre el agua,

su vuelo y descensos de artefacto aéreo,

sus nervios en cortes y secuencias,

su esnobismo de prendedor con alas.

Lo mejor del río fue la libélula

persistente sobre la superficie

con sus giros en línea y su atropello:

una ráfaga azulmarrón

aliada del aire y de la luz.

Vibrando cabeza y alas,

vuela estática

y luego se mueve: es el verde abajo

de árboles y plantas;

el violeta del agua honda

que hay en las piedras. 


\section{III. (DE "ENFERMA")}

Inmediata la desaparición del dolor, la llegada de las visitas, la taza de café. Reciente la despedida, los domingos, el dulce en la boca. Remota la noche de ayer, la anterior, que es como todas: sola y con miedo. Los médicos dicen otra cosa para tu memoria. Hablan de ti como si no estuvieras. Julia y yo te miramos preguntándonos si entiendes todo esto, si sabes hacia dónde vas y hacia dónde nos llevas. Serán días más de ella que de nadie, tal vez confusos pero con euforia; habrá momentos buenos, ¿no ha sido siempre así? ¿No es acaso igual para todos? Dejará libros, verá más fotografías, ¿y la música? La música es un piano, pero también el agua cuando la abrimos a uno y otro costado de nuestro cuerpo. Te repito qué es la música, en dónde se esconde, de dónde brota. Y, sí, tendrás menos miedo al dejar de preocuparte por lo que sucederá; vas a ir olvidando tramos y apagando luces.

Hablas del valle tras la sequía. De la velocidad del fuego cuando avanza sobre pajas y maderos. De esa imagen que puede ser un reflejo o una simple introspección: algo que se desplaza lentamente hacia la orilla; una hoja, un tronco, el resto de algo más grande en la superficie. Con el azul de la llama, tus ojos incendian lo que relatan de manera accidentada: el movimiento de algo sorprendente que al permanecer se volvió un enigma. ¿De qué estás hablando?

Nuestros nombres te son piedras y nuestras preguntas, un eco que no escuchas. Descubren la sal del mar cuando dicen que no eres la misma. Todo eso fue antes; antes de la enfermedad, antes del exilio. Al verte ahora, nadie creería que fuiste aquélla, pero ¿no es esa nuestra historia y la de todos?

Me siento a mirar contigo la corriente. El agua crecida y revuelta; las piedras grandes con sedimentos en su costa. Río de estuario, de ancha desembocadura que no vemos desde aquí ni por ahora. 


\section{IV. (DE “EL VIAJE")}

Quito el polvo de habitaciones y muebles, de la sábila y de los libros.

¿Para qué limpiarlo?

Volverá pronto a recobrar sus sitios

el polvo que es la tierra, la tierra que es roca, la roca sólida que se transmuta.

Aquí, donde van y vienen disparos, -matadero de veinte guerras simultáneasrecibo el pan fresco del día, la fruta recién cortada, lo álgido del café, el cuerpo de un hombre.

Se está cayendo a pedazos todo, allá afuera. A veces cuesta dormir, conciliar imágenes de migración y destierro. Sin embargo recibo el ritmo de otra sangre, su pulso de silencio enamorado, su gestión de perfectos pormenores. 


\section{V. ( FRAGMENTO DE "SOLO Y ENFERMA")}

La mañana que te visité afuera las palmeras se arqueaban.

Tu voz de enfermo se perdía bajo la tormenta.

Notaba yo más los gestos

de tu cuerpo estrecho, de tu cara de ave, de los huesos y venas de tus manos, que las palmeras

detrás de los cristales como cántaros.

Todo fue un sueño, pensé al salir de tu casa.

Recorrí varias calles y dudé:

¿Será que sólo he quedado yo

sobre la faz de la tierra?

Volteaba hacia las ventanas

en busca de alguien que me mirara

pero no había nadie.

Los muros repletos de humedad

los muros con graffiti

los muros con hormigas

los muros que guardan baldíos

y lotes abandonados a la basura

los muros que ocultan

los muros ¿enemigos?

Parecía que sólo ellos me hablaban:

“Ayer recorrí Tebas.

Al final de una larga pared había una pileta.

Aguardé mi turno.

Con el agua en la frente

me incliné con devoción.

Después, ya lejos de todos, eché a andar entre las ruinas

para siempre". 
CITAM Derechos Reservados.

La reproducción total o parcial de este artículo se podrá hacer si el ITAM otorga la autorización previamente por escrito. 